Full length article

\title{
14-O-Methylmorphine: A Novel Selective Mu-Opioid Receptor Agonist with High Efficacy and Affinity
}

\author{
Ferenc Zádor ${ }^{\mathrm{b}, 1}$, Mihály Balogh ${ }^{\mathrm{a}, 1}$, András Váradic ${ }^{\mathrm{c}}$ Zoltán S. Zádori ${ }^{\mathrm{a}}$, Kornél Király ${ }^{\mathrm{a}}$, \\ Edina Szú́cs $^{\mathrm{b}}$, Bence Varga ${ }^{\mathrm{a}}$, Bernadette Lázár ${ }^{\mathrm{a}}$, Sándor Hosztafi ${ }^{\mathrm{c}}$, Pál Riba ${ }^{\mathrm{a}}$, Sándor Benyhe ${ }^{\mathrm{b}}$, \\ Susanna Fürst ${ }^{\mathrm{a}}$, Mahmoud Al-Khrasani ${ }^{\mathrm{a}}{ }^{\mathrm{a}}$ \\ a Department of Pharmacology and Pharmacotherapy, Faculty of Medicine, Semmelweis University, Nagyvárad tér 4, P.O. Box 370, H-1445 Budapest, Hungary \\ b Institute of Biochemistry, Biological Research Centre of the Hungarian Academy of Sciences, Temesvári krt. 62., H- 6726 Szeged, Hungary \\ c Department of Pharmaceutical Chemistry, Semmelweis University, Högyes Endre u., 9. H-1092 Budapest, Hungary
}

\section{A R T I C L E I N F O}

\section{Keywords:}

14-O-methylmorphine

Morphine

Receptor binding

Intrinsic efficacy

Antinociception

Gastrointestinal transit

\begin{abstract}
A B S T R A C T
14-O-methyl (14-O-Me) group in morphine-6-O-sulfate (M6SU) or oxymorphone has been reported to be essential for enhanced affinity, potency and antinociceptive effect of these opioids. Herein we report on the pharmacological properties (potency, affinity and efficacy) of the new compound, 14-O-methylmorphine (14-O$\mathrm{MeM}$ ) in in vitro. Additionally, we also investigated the antinociceptive effect of the novel compound, as well as its inhibitory action on gastrointestinal transit in in vivo. The potency and efficacy of test compound were measured by $\left[{ }^{35}\right.$ S $]$ GTP $\gamma S$ binding, isolated mouse vas deferens (MVD) and rat vas deferens (RVD) assays. The affinity of 14-O-MeM for opioid receptors was assessed by radioligand binding and MVD assays. The antinociceptive and gastrointestinal effects of the novel compound were evaluated in the rat tail-flick test and charcoal meal test, respectively. Morphine, DAMGO, Ile ${ }^{5,6}$ deltorphin II, deltorphin II and U-69593 were used as reference compounds.

14-O-MeM showed higher efficacy $\left(\mathrm{E}_{\max }\right)$ and potency $\left(\mathrm{EC}_{50}\right)$ than morphine in MVD, RVD or $\left[{ }^{35} \mathrm{~S}\right] \mathrm{GTP} \gamma \mathrm{S}$ binding. In addition, 14-O-MeM compared to morphine showed higher affinity for $\mu$-opioid receptor (MOR). In vivo, in rat tail-flick test 14-O-MeM proved to be stronger antinociceptive agent than morphine after peripheral or central administration. Additionally, both compounds inhibited the gastrointestinal peristalsis. However, when the antinociceptive and antitransit doses for each test compound are compared, 14-O-MeM proved to have slightly more favorable pharmacological profile.

Our results affirm that 14-O-MeM, an opioid of high efficacy and affinity for MOR can be considered as a novel analgesic agent of potential clinical value.
\end{abstract}

\section{Introduction}

The opium-derived analgesic morphine is widely used in clinic to manage moderate to severe pain and considered to be the prototypical non-peptide opioid agonist, with a high selectivity for the $\mu$-opioid receptor (MOR) subtype. Besides $\mu$-opioid receptors, mammalians are also hosting $\kappa$-opioid receptors (KOR) and $\delta$-opioid receptors (DOR). These receptors are G-protein-coupled receptors (GPCR) and they are expressed at central and peripheral relay points of nociceptive transmission (Fürst, 1999) and activated by endogenous or exogenous opioids. Upon their activation besides antinociceptive effect other measurable unwanted actions like respiratory depression, sedation or constipation are evoked (Debono et al., 2013; Koob et al., 1998).
One of the main goals of opioid researchers is to find opioid ligands of better pharmacological profiles than that of the currently available. 14-methoxy analogues of oxymorphone (14-O-methyloxymorphone) or morphine-6-O-sulfate have been reported to have higher affinity for opioid receptors and enhanced antinociceptive action compared to the parent compounds (Fürst et al., 2005; Khalefa et al., 2013; Lacko et al., 2012; Spetea et al., 2004). To the best of our knowledge, the in vitro and in vivo pharmacological profile of 14-methoxy analogues of morphine, particularly, 14-O-methylmorphine (Fig. 1) has not been reported yet.

Therefore, the aim of the present work was to synthesize 14-Omethylmorphine, assess its receptor preference (selectivity and affinity) for opioid receptors in biological (MVD, mouse vas deferens) and biochemical (equilibrium competition binding) assays. Further aim was to

\footnotetext{
* Corresponding author.

E-mail address: al-khrasani.mahmoud@med.semmelweis-univ.hu (M. Al-Khrasani).

${ }^{1}$ These authors are equally contributed to the work.
} 
<smiles>CN1CC[C@]23CC1c1c(O)ccc(c12)CCN3C</smiles><smiles></smiles>

Morphine

Fig. 1. The structure of morphine and 14-O-methylmorphine (14-O-MeM).

determine the potency and efficacy of 14-O-methylmorphine and compare them to the parent compound, morphine and to other, selective $\mu$-, $\delta$ - and $\mathrm{\kappa}$-opioid receptor agonists, such as $\left[\mathrm{D}-\mathrm{Ala}^{2}, \mathrm{~N}-\mathrm{Me}-\right.$ $\mathrm{Phe}^{4}, \mathrm{Gly}_{\mathrm{ol}}{ }^{5}$ ] enkephalin (DAMGO), deltorphin II and U-69593, respectively, in mouse and rat vas deferens and functional $\left[{ }^{35} \mathrm{~S}\right] \mathrm{GTP} \gamma \mathrm{S}$ binding. Further objective was to determine the antinociceptive effect of 14-O-methylmorphine, as well as its inhibitory effect on gastrointestinal transit applying rat tail-flick and charcoal meal assays, respectively and compare them to the effects of morphine.

\section{Materials and methods}

\subsection{Animals}

Male NMRI mice (35-45 g) for experiments designed for MVD and male Wistar rats for rat tail-flick test (140-240 g) and for RVD and gastrointestinal charcoal meal test $(160-260 \mathrm{~g})$ were used. Mice and rats were obtained from Toxi-Coop Zrt. (Budapest, Hungary) and the Animal House of Semmelweis University (Budapest, Hungary), respectively. Animals were housed in the local animal house of the Department of Pharmacology and Pharmacotherapy, Semmelweis University (Budapest, Hungary).

For in vitro receptor binding assays male and female Wistar rats (250-300 g body weight) and male guinea pigs ( $\sim 400-700 \mathrm{~g}$ body weight, LAL/HA/BR strain) were used. Rats were purchased from and housed in the local animal house of the Biological Research Centre of the Hungarian Academy of Sciences (Szeged, Hungary), while guinea pigs were purchased from and housed in LAB-ÁLL Bt. (Budapest, Hungary).

The animals were kept in a temperature controlled room $\left(21-24{ }^{\circ} \mathrm{C}\right)$ under a 12:12 light and dark cycle and were provided with water and food ad libitum. All housing and experiments were handled in accordance with the European Communities Council Directives (2010/ 63/EU), the Hungarian Act for the Protection of Animals in Research (XXVIII.tv. 32.§) and local animal care committee (PEI/001/276-4/ 2013). All the researchers did the best effort to minimize the number of animals and their suffering.

\subsection{Chemicals}

14-O-methylmorphine (Fig. 1) was synthesized as described under Section 2.3. Tris-HCl, EGTA, $\mathrm{NaCl}, \mathrm{MgCl}_{2} \times 6 \mathrm{H}_{2} \mathrm{O}$, GDP, the GTP analogue GTP $\gamma$ S, the DOR and KOR antagonist naltrindole and norbinaltorphimine, respectively and the KOR agonist U-69593 were purchased from Sigma-Aldrich (Budapest, Hungary). The MOR selective antagonist cyprodime was provided by Dr. Helmut Schmidhammer (Department of Pharmacy, University of Innsbruck, Austria) and the MOR agonist enkephalin analogue Tyr-D-Ala-Gly-(NMe)Phe-Gly-ol (DAMGO) and the DOR selective agonist deltorphin II (Delt II) were obtained from Bachem Holding AG (Bubendorf, Switzerland) and Tocris Bioscience (through Biomedica Hungária Kft., Budapest, Hungary). The selective DOR agonist Ile ${ }^{5,6-}$ deltorphin II (IleDelt II) was synthesized in the Laboratory of Chemical Biology group of the Biological Research Centre of the Hungarian Academy of Sciences (Szeged, Hungary). The non-selective opioid receptor antagonist naloxone was kindly provided by the company Endo Laboratories DuPont de Nemours (Wilmington, DE, USA). Morphine hydrochloride was obtained from (Alkaloida-ICN, Tiszavasvári, Hungary). Ligands were dissolved in water and were stored in $1 \mathrm{mM}$ stock solution at $20^{\circ} \mathrm{C}$ for in vitro tests. Ligands used for in vivo assays were dissolved in saline prior to the experiments.

The radiolabeled GTP analogue, $\left[{ }^{35} \mathrm{~S}\right] \mathrm{GTP} \gamma \mathrm{S}$ (specific activity: 1000 $\mathrm{Ci} / \mathrm{mmol}$ ) was purchased from Hartmann Analytic (through Izotóp Intézet Kft., Budapest, Hungary). [ $\left.{ }^{3} \mathrm{H}\right]$ DAMGO (specific activity: $38.8 \mathrm{Ci} / \mathrm{mmol}$ ), [ $\left.{ }^{3} \mathrm{H}\right]$ IleDelt II (specific activity: $19,6 \mathrm{Ci} / \mathrm{mmol}$ ) were radiolabeled by the Laboratory of Chemical Biology group in BRC (Szeged, Hungary). $\left[{ }^{3} \mathrm{H}\right] \mathrm{U}-69593$ (specific activity: 43,6 Ci/mmol) were purchased from PerkinElmer (through Per-Form Hungária Kft., Budapest, Hungary). The UltimaGold ${ }^{\mathrm{TM}}$ MV aqueous scintillation cocktail was purchased from PerkinElmer (through Per-Form Hungária Kft., Budapest, Hungary).

\subsection{Chemistry}

14-O-methylmorphine was synthesized as described previously (Lacko et al., 2012). Briefly, 14-OH-codeinone was used as the starting material (Fig. 2). O-methylation was carried out by dimethyl sulfate in the presence of sodium hydride in $\mathrm{N}, \mathrm{N}$-dimethylformamide (Kobylecki et al., 1982; Razdan and Ghosh, 1980). 14-O-methylcodeinone was selectively demethylated in the 3-O position by refluxing in aqueous hydrogen bromide (Schmidhammer et al., 1990). The resulting 14-Omethylmorphinone was reduced by sodium borohydride in methanol to give 14-O-methylmorphine.

NMR data: Mp.: $221-223{ }^{\circ} \mathrm{C} .{ }^{1} \mathrm{H}$ NMR $\left(600 \mathrm{MHz}, \mathrm{CDCl}_{3}\right): \delta=6.62$ (d, $J=8.1 \mathrm{~Hz}, \mathrm{H}-2,1 \mathrm{H}$ ), 6.48 (d, $J=8.1 \mathrm{~Hz}, \mathrm{H}-1,1 \mathrm{H}$ ), 5.88 (d, $J=$ $9.9 \mathrm{~Hz}, \mathrm{H}-7,1 \mathrm{H}$ ), 5.47 (dd, $J=9.9,3.2 \mathrm{~Hz}, \mathrm{H}-8,1 \mathrm{H}), 4.87$ (d, $J=$ $6.4 \mathrm{~Hz}, \mathrm{H}-5,1 \mathrm{H}$ ), 4.60 (m, H-6, 1H), 3.20 (s, 14-OMe, 3H), 2.44 (s, $\mathrm{NMe}, 3 \mathrm{H}) \mathrm{ppm} .{ }^{13} \mathrm{C}$ NMR $\left(150 \mathrm{MHz}, \mathrm{CDCl}_{3}\right): \delta=144.6,138.6,137.8$, 132.8, 129.0, 126.2, 119.5, 117.1, 90.2, 74.9, 66.0, 57.4, 50.6, 47.6, $46.0,43.3,30.6,29.9,22.6 \mathrm{ppm}$.

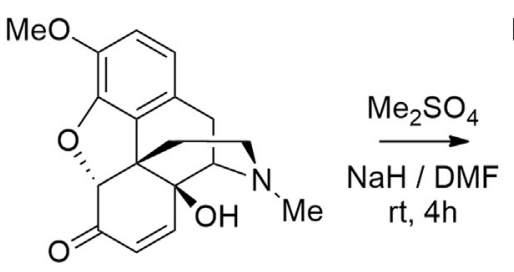

14-OH-codeinone

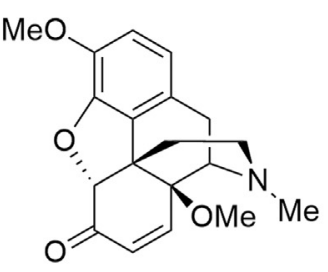

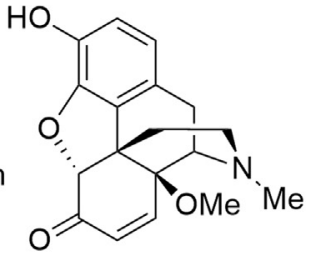

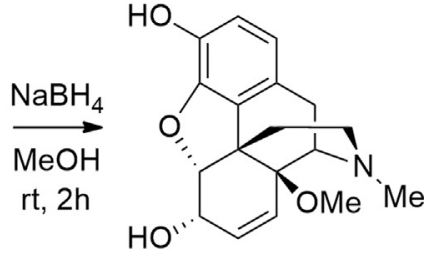

14-O-MeM

Fig. 2. The synthesis of 14-O-methylmorphine (14-O-MeM). For further information see Section 2.3 . 


\subsection{Receptor binding assays}

\subsubsection{Membrane preparations}

Rats and guinea pigs were decapitated and their brains were quickly removed. The brains were prepared for membrane preparation according to Benyhe and co-workers (Benyhe et al., 1997). The brain membrane homogenates were partly used for competition binding experiments and partly were further prepared for the $\left[{ }^{35} \mathrm{~S}\right] \mathrm{GTP} \gamma \mathrm{S}$ binding assays according to Zádor and co-workers (Zádor et al., 2014). In brief, firstly the brains were homogenized, centrifuged in ice-cold $50 \mathrm{mM}$ Tris- $\mathrm{HCl}\left(\mathrm{pH}\right.$ 7.4) buffer and incubated at $37^{\circ} \mathrm{C}$ for $30 \mathrm{~min}$ in a shaking water-bath (for details see Benyhe et al., 1997). After incubation the centrifugation was repeated as described before and the final pellet was suspended in $50 \mathrm{mM}$ Tris- $\mathrm{HCl} \mathrm{pH} 7.4$ buffer containing $0.32 \mathrm{M}$ sucrose and stored at $-80{ }^{\circ} \mathrm{C}$ for further use. For the $\left[{ }^{35} \mathrm{~S}\right] \mathrm{GTP} \gamma \mathrm{S}$ binding experiments the final pellet of rat brain membrane homogenate was suspended in ice-cold TEM (Tris-HCl, EGTA, $\mathrm{MgCl}_{2}$ ) buffer and stored at $-80{ }^{\circ} \mathrm{C}$ for further use.

\subsubsection{Radioligand competition binding assays}

In competition binding assays the affinity of an unlabeled compound is analyzed by measuring radioligand specific binding in the presence of increasing concentrations of the unlabeled compound in question (Frey and Albin, 2001).

Aliquots of frozen rat and guinea pig brain membrane homogenates were centrifuged $\left(40,000 \mathrm{~g}, 20 \mathrm{~min}, 4^{\circ} \mathrm{C}\right)$ to remove sucrose and the pellets were suspended in $50 \mathrm{mM}$ Tris- $\mathrm{HCl}$ buffer $(\mathrm{pH}$ 7.4). Brain membranes homogenates containing $0.3-0.5 \mathrm{mg} / \mathrm{ml}$ of protein were incubated in the presence of increasing concentrations $(0.1 \mathrm{nM}-10 \mu \mathrm{M})$ of 14-O-methylmorphine or morphine or with the equivalent homologues ligand of the radioligands (DAMGO, Ile ${ }^{5,6-}$ deltorphin II and U69593 for control) with $\sim 1-3 \mathrm{nM}$ concentrations of the given radioligand. The incubation temperatures and times were dependent from the radioligand and were the following: $\left[{ }^{3} \mathrm{H}\right]$ DAMGO and $\left[{ }^{3} \mathrm{H}\right]$ Ile ${ }^{5,6-}$ deltorphin II in $35{ }^{\circ} \mathrm{C}$ for $\left.45 \mathrm{~min},{ }^{3} \mathrm{H}\right] \mathrm{U}-69593$ in $30{ }^{\circ} \mathrm{C}$ for $30 \mathrm{~min}$. Experiments with $\left[{ }^{3} \mathrm{H}\right] \mathrm{U}-69593$ were performed in guinea pig brain membrane homogenates, since the guinea pig brain has significantly more $\kappa$-opioid receptors than the rat brain, while the rest of the radioligands $\left(\left[{ }^{3} \mathrm{H}\right] \mathrm{DAMGO}\right.$ and $\left[{ }^{3} \mathrm{H}\right] \mathrm{Il} \mathrm{e}^{5,6-}$ deltorphin II) were examined in rat brain membrane homogenates. The non-specific and total binding were determined in the presence of $10 \mu \mathrm{M}$ unlabeled naloxone and in the absence of unlabeled compounds, respectively. The reaction was terminated by rapid filtration under vacuum (Brandel M24R Cell Harvester), and washed three times with $5 \mathrm{ml}$ ice-cold $50 \mathrm{mM}$ Tris- $\mathrm{HCl}$ through Whatman GF/C $\left(\left[{ }^{3} \mathrm{H}\right] \mathrm{DAMGO},\left[{ }^{3} \mathrm{H}\right] \mathrm{Il} \mathrm{e}^{5,6-}\right.$ deltorphin II or GF/B ( $\left.\left.{ }^{3} \mathrm{H}\right] \mathrm{U}-69593\right)$ ) glass fibers (GE Healthcare Life Sciences through Izinta Kft., Budapest, Hungary). The radioactivity of the filters was detected in UltimaGold $^{\mathrm{TM}}$ MV aqueous scintillation cocktail with Packard Tricarb 2300TR liquid scintillation counter. The competition binding assays were performed in duplicate and repeated at least three times.

\subsubsection{Functional $\left[{ }^{35} S\right] G T P \gamma S$ binding assays}

In $\left[{ }^{35} \mathrm{~S}\right] \mathrm{GTP} \gamma \mathrm{S}$ binding experiments we measure the GDP $\rightarrow$ GTP exchange of the $G_{\alpha i / o}$ protein in the presence of a given ligand to measure ligand potency and the maximal efficacy of receptors G-protein (Strange, 2010). The nucleotide exchange is monitored by a radioactive, non-hydrolysable GTP analogue, $\left[{ }^{35} \mathrm{~S}\right] \mathrm{GTP} \gamma \mathrm{S}$.

The functional $\left[{ }^{35} \mathrm{~S}\right] \mathrm{GTP} \gamma \mathrm{S}$ binding experiments were performed as previously described (Sim et al., 1995; Traynor and Nahorski, 1995), with modifications. Briefly the rat or guinea pig brain membrane homogenates containing $\sim 10 \mu \mathrm{g} / \mathrm{ml}$ protein were incubated at $30{ }^{\circ} \mathrm{C}$ for $60 \mathrm{~min}$ in Tris-EGTA buffer (pH 7.4) composed of $50 \mathrm{mM}$ Tris- $\mathrm{HCl}$, $1 \mathrm{mM}$ EGTA, $3 \mathrm{mM} \mathrm{MgCl}$, $100 \mathrm{mM} \mathrm{NaCl}$, containing $0.05 \mathrm{nM}\left[{ }^{35} \mathrm{~S}\right] \mathrm{G}-$ $\mathrm{TP} \gamma \mathrm{S}$ and increasing concentrations $(0.1 \mathrm{nM}-10 \mu \mathrm{M})$ of $14-O$-methylmorphine, morphine, DAMGO, deltorphin II or U-69593 in the presence or absence of $10 \mu \mathrm{M}$ cyprodime, naltrindole or norbinaltorphimine and excess GDP $(30 \mu \mathrm{M})$ in a final volume of $1 \mathrm{ml}$. 14-O-methylmorphine and morphine were incubated both with guinea pig and rat brain membrane homogenates, while experiments with U-69593 and norbinaltorphimine were performed only with guinea pig brain membrane homogenates.

Total binding was measured in the absence of test compounds, while non-specific binding was determined in the presence of $10 \mu \mathrm{M}$ unlabeled GTP $\gamma$ S. The bound and unbound $\left[{ }^{35} \mathrm{~S}\right] \mathrm{GTP} \gamma \mathrm{S}$ was separated as described in Section 2.4.2 through Whatmann GF/B glass fibers (GE Healthcare Life Sciences through Izinta Kft., Budapest, Hungary). The radioactivity of the filters was also detected as described in Section 2.4.2. $\left[{ }^{35} \mathrm{~S}\right] \mathrm{GTP} \gamma \mathrm{S}$ binding experiments were performed in triplicates and repeated at least three times.

\subsection{Isolated organs}

\subsubsection{Mouse vas deferens}

Vasa deferentia were taken out from male mice. The preparation and the experimental procedures were done as described previously (Rónai et al., 1977). Briefly, vasa deferentia were cleaned out from tissues and suspended between two electrodes in organ baths of $5 \mathrm{ml}$ volume with $0.1 \mathrm{~g}$ initial tension. The upper and the lower electrodes have ring and straight form, respectively. The organ baths were filled with $\mathrm{Mg}^{2+}$ free Krebs solution, of the following composition $(\mathrm{mM} / \mathrm{L})$ : NaCl, 118.0; Na$\mathrm{HCO}_{3}, 25.0 ; \mathrm{KCl}, 4.7 ; \mathrm{KH}_{2} \mathrm{PO}_{4}, 1.2$; glucose, 11.0; $\mathrm{CaCl}_{2}, 2.5$ aerated with carbogen $\left(95 \% \mathrm{O}_{2}+5 \% \mathrm{CO}_{2}\right)$ and kept at $31{ }^{\circ} \mathrm{C}$. The stimulation parameters were as follows: field stimulation, pairs $(100 \mathrm{~ms}$ pulse distance) of rectangular impulses ( $1 \mathrm{~ms}$ pulse width, $9 \mathrm{~V} / \mathrm{cm}$ i.e. supramaximal intensity) were repeated by $10 \mathrm{~s}$. The muscle contractions were monitored by computer.

\subsubsection{Rat vas deferens}

Vasa deferentia were removed from Wistar male rats and the experimental procedure was as described for mouse vas deferens, with the following modifications: use of Krebs solution, $0.5 \mathrm{~g}$ initial tension and the electrical field stimulation (pulse width, $1 \mathrm{~ms}$; intensity, $9 \mathrm{~V} / \mathrm{cm}$ ) was delivered at $0.1 \mathrm{~Hz}$ frequency.

\subsubsection{Experimental paradigms of mouse and rat vas deferens}

The experimental paradigm was similar as described previously (Lacko et al., 2012). Briefly, after the equilibration time (30-40 min and 90-120 min for mouse vas deferens and rat vas deferens respectively) the first dose of agonist was added and the concentration-effect curves were constructed in a cumulative manner. After that, the preparations were washed and allowed to regain their pre-drug twitch height. Then vasa deferentia were equilibrated with antagonist for $20 \mathrm{~min}$, and without washing a single concentration of agonist was added. To determine dissociation constants of the antagonist, dose ratio (DR) values were obtained by the single-dose method described by Kosterlitz and Watt (1968).

\subsection{Antinociceptive tests (rat tail-flick test)}

Rat tail-flick test was performed in order to analyze the antinociceptive properties of 14-O-methylmorphine. The test compounds were dissolved in saline and injected s.c. into the animals. The experiments were carried out as described earlier (Fürst et al., 1993). Briefly, a beam of light was focused onto the dorsum of the lower third of the rat tail. Then, the time latencies until the rats flick their tales were determined before (baseline) and after injection of the test compounds. Twice of the baseline latency was used as an arbitrary cut off time in order to avoid tissue damage. The antinociceptive activity was assessed 30, 60 and 120 min after s.c. drug administration and 10, 20, 30 and 60 min after i.c.v. administration. 


\subsection{Determination the effect of 14-O-methylmorphine on gastrointestinal transit}

The effect of 14-O-methylmorphine compared to that of morphine on gastrointestinal transit was determined in rats applying the charcoal meal method, as reported previously by Vera et al. (2011), with minor modifications. Briefly, male Wistar rats were fasted $6 \mathrm{~h}$ prior to the experiments, with free access to water. At the time of the experiment, a charcoal suspension (10\% charcoal in $5 \%$ gum arabic) was given in a volume of $1 \mathrm{ml} /$ animal by an oral gavage. $30 \mathrm{~min}$ later rats were euthanized, their entire small intestines were removed, and the distance travelled by the charcoal suspension was expressed as a percentage of total small intestine length. 14-O-methylmorphine and morphine $(0.25 \mathrm{ml} / 100 \mathrm{~g})$ were given s.c. $30 \mathrm{~min}$ before the application of charcoal suspension.

\subsection{Data analysis}

\subsubsection{Receptor binding assays}

The specific binding of the radiolabeled compound $\left(\left[{ }^{3} \mathrm{H}\right]\right.$ ligand, $\left[{ }^{35} \mathrm{~S}\right] \mathrm{GTP} \gamma \mathrm{S}$ ) was calculated by the subtraction of non-specific binding from total binding and was given in percentage. Data was normalized to total specific binding, which was settled $100 \%$, which in case of $\left[{ }^{35} \mathrm{~S}\right] \mathrm{GTP} \gamma \mathrm{S}$ also represents the level of basal activity of the G-protein. Individual data sets were presented in the function of the applied ligand concentration range in logarithm form and were individually fitted with the professional curve fitting program, GraphPad Prism 5.0 (GraphPad Prism Software Inc., San Diego, CA), using non-linear regression. In the radioligand competition binding assays the 'One-site competition' equation was applied to determine $\mathrm{IC}_{50}$ (unlabeled ligand affinity) and to further calculate the inhibitory constant $\left(\mathrm{K}_{\mathrm{i}}\right)$ value according to the Cheng-Prusoff equation (Cheng and Prusoff, 1973). Selectivity ratios were calculated based on the $\mathrm{K}_{\mathrm{i}}$ values. In case of $\left[{ }^{35} \mathrm{~S}\right] \mathrm{GTP} \gamma \mathrm{S}$ binding assays the 'Sigmoid concentration-response' equation was applied to obtain the maximum G-protein efficacy $\left(\mathrm{E}_{\max }\right)$ and ligand potency $\left(\mathrm{EC}_{50}\right)$, respectively. These individual parameters were averaged, statistically analyzed and presented as means \pm S.E.M. in Tables 1 and 2. For representation the individual specific binding data points were also presented as means \pm S.E.M., fitted as mentioned above and shown in Figs. 3 and 4.

\subsubsection{Mouse and rat vas deferens bioassays}

Individual logarithmic concentration-response curves were constructed and the $50 \%$ effective concentration $\left(\mathrm{EC}_{50}\right)$ and maximal effect $\left(E_{\max }\right)$ were determined with SigmaPlot program (Systat Software Inc., Jose, California). In mouse vas deferens, the equilibrium dissociation constant of naloxone $\left(\mathrm{K}_{\mathrm{e}}\right)$ was calculated with the single-dose method as described previously (Kosterlitz and Watt, 1968). Antagonist affinities $\left(\mathrm{K}_{\mathrm{e}}\right)$ were calculated as follows: $\mathrm{Ke}=$ [antagonist concentration] $/[$ dose ratio-1].

\subsubsection{Rat tail-flick test and gastrointestinal transit}

In rat tail-flick test, after the dose-response curves were constructed the dose necessary to produce a $50 \%$ effect $\left(\mathrm{ED}_{50}\right)$ and $95 \%$ confidence limits were calculated by the Litchfield-Wilcoxon method (Litchfield and Wilcoxon, 1949).

In case of gastrointestinal transit test the doses caused 50\% inhibition on gastrointestinal transit $\left(\mathrm{ID}_{50}\right)$ were calculated from the linear regression of dose-response curves and 95\% confidence limits were calculated by the Litchfield-Wilcoxon method (Litchfield and Wilcoxon, 1949).

\subsubsection{Statistical analysis}

For multiple data set statistical analysis One-way ANOVA with Tukey's multiple comparison post hoc test, while for two data sets unpaired $t$-test with two-tailed $\mathrm{P}$ value was used. One sample $t$-test with a hypothetical value of $100 \%$ or One-way ANOVA with Dunnett's multiple comparison post hoc test was applied when $K_{i} \pm$ S.E.M. or multiple $\mathrm{E}_{\max } \pm$ S.E.M. values, respectively were compared to the normalized total specific binding $(100 \%)$ obtained from receptor binding assays. Statistical analysis was performed with GraphPad Prism 5.0 program; significance was accepted at $\mathrm{P}<0.05$ level.

\section{Results}

\subsection{Receptor binding assays}

\subsubsection{Binding affinity measurements in radioligand competition binding} assays

To test the opioid binding affinity of 14-O-methylmorphine competition binding assays were performed with $\mu$-, $\delta$ - and к-opioid receptor specific radioligands, $\left[{ }^{3} \mathrm{H}\right] \mathrm{DAMGO},\left[{ }^{3} \mathrm{H}\right] \mathrm{Ile}^{5,6-}$ deltorphin II and $\left[{ }^{3} \mathrm{H}\right] \mathrm{U}-69593$, respectively. Experiments with $\left[{ }^{3} \mathrm{H}\right]$ DAMGO and $\left[{ }^{3} \mathrm{H}\right]$ $\mathrm{Ile}^{5,6-}$ deltorphin II were done in rat whole brain membrane homogenates, while $\left[{ }^{3} \mathrm{H}\right] \mathrm{U}-69593$ binding assays were performed in guinea pig whole brain membrane homogenates. In the binding assays all radioligand's total specific binding was reduced by their own unlabeled homologous ligand with a $K_{i}$ value in the nanomolar range (Table 1), which indicates the adequate performance and selectivity of the radioligands and are in accordance with previous data (Lacko et al., 2012).

According to the results 14-O-methylmorphine showed a very high affinity for $\mu$-opioid receptor, since it inhibited total specific $\left[{ }^{3} \mathrm{H}\right]$

Table 1

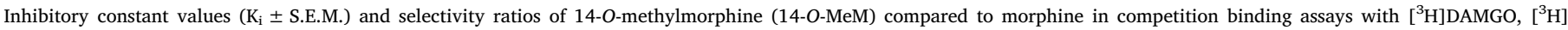

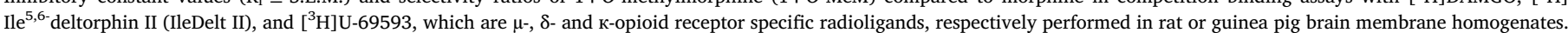
The unlabeled form of the radioligands are also indicated for control and for further comparison. Data were analyzed as described in Sections 2.8.1 and 2.8.4.

\begin{tabular}{|c|c|c|c|c|c|c|}
\hline \multirow[t]{2}{*}{ Compounds } & \multicolumn{3}{|l|}{$\mathrm{K}_{\mathrm{i}} \pm$ S.E.M. (nM) } & \multicolumn{3}{|c|}{ Selectivity ratio } \\
\hline & {$\left[{ }^{3} \mathrm{H}\right]$ DAMGO $(\mu)^{1}$} & {$\left[{ }^{3} \mathrm{H}\right]$ IleDelt II $(\delta)^{1}$} & {$\left[{ }^{3} \mathrm{H}\right] \mathrm{U}-69593(\kappa)^{2}$} & $\delta / \mu$ & $\kappa / \mu$ & $\delta / \kappa$ \\
\hline 14-O-МеM & $\begin{array}{l}0.16 \pm 0.03^{\mathrm{a}} \\
(\mathrm{n}=5)\end{array}$ & $\begin{array}{l}198.5 \pm 92.3 \\
(\mathrm{n}=6)\end{array}$ & $\begin{array}{l}216.5 \pm 60.98 \\
(n=3)\end{array}$ & 1240 & 1356 & 1 \\
\hline Morphine & $\begin{array}{l}0.87 \pm 0.11 \\
(\mathrm{n}=7)\end{array}$ & $\begin{array}{l}314.1 \pm 149.2 \\
(\mathrm{n}=6)\end{array}$ & $\begin{array}{l}\text { N.D. }{ }^{3} \\
(n=4)\end{array}$ & 361 & - & - \\
\hline Homologous ligand $^{4}$ & $\begin{array}{l}0.7 \pm 0.21 \\
(\mathrm{n}=5)\end{array}$ & $\begin{array}{l}4.95 \pm 1.61 \\
(n=5)\end{array}$ & $\begin{array}{l}13.34 \pm 3.02 \\
(n=4)\end{array}$ & - & - & - \\
\hline
\end{tabular}

\footnotetext{
${ }^{1}$ Performed in rat brain membrane homogenates.

${ }^{2}$ Performed in guinea pig brain membrane homogenates.

${ }^{3}$ The compound did not alter significantly (One-sample $t$-test) the total specific radioligand binding (100\%), the $\mathrm{K}_{\mathrm{i}}$ value cannot be interpreted (N.D.: not determined).

${ }^{4}$ Indicates the unlabeled form of the radioligands and represent a control for the assay ( $\mu$ : DAMGO $\delta$ : IleDelt II, $\kappa$ : U-69593).

Note: $\mu, \delta$ and $\kappa$ indicates the three classic opioid receptors.

${ }^{\text {a }} \mathrm{P}<0.01$ compared to morphine (One-way ANOVA, Tukey's multiple comparisons post hoc test).
} 
Table 2

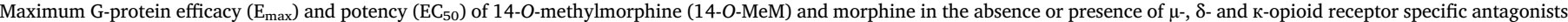

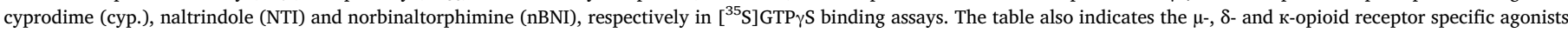

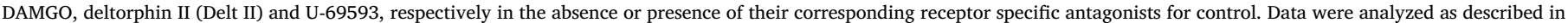
Sections 2.8 .1 and 2.8.4.

\begin{tabular}{|c|c|c|c|c|c|}
\hline \multicolumn{3}{|c|}{ Agonist alone } & \multicolumn{3}{|c|}{$+10 \mu \mathrm{M}$ antagonist } \\
\hline Compounds & $E_{\max } \pm$ S.E.M. (\%) & EC $_{50} \pm$ S.E.M. (nM) & Compounds & $E_{\max } \pm$ S.E.M. (\%) & $\mathrm{EC}_{50} \pm$ S.E.M. (nM) \\
\hline \multirow[t]{3}{*}{$\begin{array}{l}\text { 14-O-MeM } \\
(\mathrm{n}=6)^{1}\end{array}$} & $173.7 \pm 0.79^{\mathrm{a}, \mathrm{c}}$ & $93.12 \pm 18.55$ & $\begin{array}{l}+ \text { cyp. }(\mu) \\
(\mathrm{n}=5)^{1}\end{array}$ & $118.7 \pm 2.1^{\mathrm{d}}$ & $>1000$ \\
\hline & - & - & + NTI $(\delta)$ & & \\
\hline & & & $(\mathrm{n}=5)^{1}$ & $104.8 \pm 3.13^{\mathrm{d}}$ & N.D. ${ }^{3}$ \\
\hline$(\mathrm{n}=5)^{2}$ & $135.6 \pm 3.47^{\mathrm{b}}$ & $324.4 \pm 216.2$ & $\begin{array}{l}+\mathrm{nBNI}(\kappa) \\
(\mathrm{n}=5)^{2}\end{array}$ & $108 \pm 3.63^{d}$ & N.D. ${ }^{3}$ \\
\hline \multirow[t]{3}{*}{$\begin{array}{l}\text { Morphine } \\
(\mathrm{n}=7)^{1}\end{array}$} & $145.3 \pm 6.86^{\mathrm{c}}$ & $388.1 \pm 140.7$ & $\begin{array}{l}+ \text { cyp. }(\mu) \\
(\mathrm{n}=5)^{1}\end{array}$ & $106.9 \pm 2.65^{\mathrm{d}}$ & N.D. ${ }^{3}$ \\
\hline & - & - & + NTI $(\delta)$ & & \\
\hline & & & $(\mathrm{n}=5)^{1}$ & $105.9 \pm 3.95^{\mathrm{d}}$ & N.D. ${ }^{3}$ \\
\hline$(\mathrm{n}=5)^{2}$ & $118.8 \pm 2.32$ & $422.2 \pm 151.9$ & + nBNI (к) & N.D. ${ }^{4}$ & N.D. ${ }^{4}$ \\
\hline $\begin{array}{l}\text { DAMGO }(\mu) \\
(n=7)^{1}\end{array}$ & $165.3 \pm 4.11$ & $197 \pm 75.44$ & $\begin{array}{l}+ \text { cyp. }(\mu) \\
(\mathrm{n}=5)^{1}\end{array}$ & $116.6 \pm 5.24^{\mathrm{d}}$ & $>1000$ \\
\hline $\begin{array}{l}\text { Delt II }(\delta) \\
(n=5)^{1}\end{array}$ & $128.9 \pm 2.57$ & $158.1 \pm 98.37$ & $\begin{array}{l}+ \text { NTI }(\delta) \\
(\mathrm{n}=5)^{1}\end{array}$ & $103.7 \pm 1.15^{\mathrm{d}}$ & N.D. ${ }^{3}$ \\
\hline $\begin{array}{l}\text { U-69593 (к) } \\
(\mathrm{n}=6)^{2}\end{array}$ & $131 \pm 2.63$ & $69.74 \pm 18.34$ & $\begin{array}{l}+ \text { nBNI (к) } \\
(\mathrm{n}=5)^{2}\end{array}$ & $108.7 \pm 3.21^{\mathrm{d}}$ & N.D. ${ }^{3}$ \\
\hline
\end{tabular}

${ }^{1}$ Performed in rat brain membrane homogenates.

${ }^{2}$ Performed in guinea pig brain membrane homogenates.

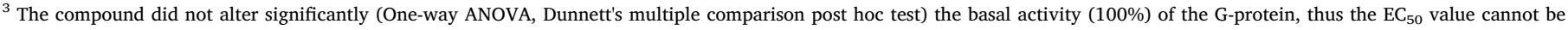
interpreted.

${ }^{4}$ Morphine alone displayed poor activity, therefore adding norbinaltorphimine was unnecessary.

Note: $\mu, \delta$ and $\kappa$ indicates the three classic opioid receptors; N.D.: not determined.

${ }^{\text {a }} \mathrm{P}<0.001$ compared to morphine and Delt II in rat brain membrane homogenates (One-way ANOVA, Tukey's multiple comparisons post hoc test).

${ }^{\mathrm{b}} \mathrm{P}<0.001$ compared to morphine in guinea pig brain membrane homogenates (One-way ANOVA, Tukey's multiple comparisons post hoc test).

${ }^{\mathrm{c}} \mathrm{P}<0.001$ between rat and guinea pig brain homogenates with either 14-O-methylmorphine or morphine (unpaired t test, two-tailed $\mathrm{P}$ value).

${ }^{\mathrm{d}} \mathrm{P}<0.001$ compared to the corresponding agonist alone (unpaired $\mathrm{t}$ test, two-tailed $\mathrm{P}$ value).

DAMGO binding with a $\mathrm{K}_{\mathrm{i}}$ of $0.16 \mathrm{nM}$ (Table 1 ), which is a fourfold and a fivefold decrease compared to DAMGO and morphine, respectively (Table 1). In the binding curves this was indicated by a left shift of 14$O$-methylmorphine curves compared to morphine and DAMGO (Fig. 3A). [ $\left.{ }^{3} \mathrm{H}\right] \mathrm{Il}{ }^{5,6-}$ deltorphin II and $\left[{ }^{3} \mathrm{H}\right] \mathrm{U}-69593$ total specific binding was reduced with a much higher $\mathrm{K}_{\mathrm{i}}$ value in the presence of 14$O$-methylmorphine (one order of magnitude, Table 1 ) than in case of $\left[{ }^{3} \mathrm{H}\right]$ DAMGO, therefore it showed lower affinity towards the $\delta$ - and $\mathrm{\kappa}-$ opioid receptor (Table 1). This was also indicated by the selectivity ratios (Table 1). Morphine reduced $\left[{ }^{3} \mathrm{H}\right] \mathrm{Ile} \mathrm{e}^{5,6-}$ deltorphin II specific binding with a 1.5 fold higher $\mathrm{K}_{\mathrm{i}}$ value compared to 14-O-methylmorphine (Fig. 3C, Table 1), however $\left[{ }^{3} \mathrm{H}\right] \mathrm{U}-69593$ specific binding remained at the total level $(100 \%)$ in the presence of morphine even in the highest applied concentrations (Table 1 ). The $\delta / \mu$ selectivity ratio of morphine was over 300 , four times lower than of 14-O-methylmorphine (Table 1). For the averaged competition binding curves see Fig. 3.

\subsubsection{Agonist activity measurements in $\left.{ }^{35} S\right] G T P \gamma S$ binding assays}

To measure the agonist activity of 14-O-methylmorphine we performed $\left[{ }^{35} \mathrm{~S}\right] \mathrm{GTP} \gamma \mathrm{S}$ binding assays, which can monitor the GPCR mediated G-protein activation, therefore the maximum efficacy and potency of a given ligand can be determined. For comparison morphine was also measured together with three other opioid receptor agonist reference compounds DAMGO, deltorphin II and U-69593 selective for $\mu$-, $\delta$ - and к-opioid receptor, respectively. All reference compounds performed adequately (Fig. 4A and C, Table 2) and were correspondent with previous results (Lacko et al., 2012).

According to the results in rat brain membrane homogenates 14-Omethylmorphine dose dependently increased $\left[{ }^{35} \mathrm{~S}\right] \mathrm{GTP} \gamma \mathrm{S}$ specific binding over basal activity (Fig. 4A) with a $173.7 \%$ maximum efficacy $\left(\mathrm{E}_{\max }\right)$ and $93.1 \mathrm{nM}$ potency $\left(\mathrm{EC}_{50}\right)$, which are improved parameters (significantly for $\mathrm{E}_{\max }$ value) compared to morphine (145.3\% and $388.1 \mathrm{nM}$; Table 2). The maximum efficacy of 14-O-methylmorphine was also higher compared to the potent $\mu$-opioid receptor selective agonist DAMGO and the $\delta$-opioid receptor selective agonist deltorphin II (165.3\% and 128.9\%; Table 2). In membrane homogenates of guinea pig brain - where KORs are expressed in significantly larger quantities compared to the rat brain - 14-O-methylmorphine increased $\left[{ }^{35} \mathrm{~S}\right] \mathrm{G}$ TP $\gamma S$ specific binding over basal activity in a less extent and showed significantly lower maximum efficacy compared to rat brain $(173.7 \%$ vs. $136 \%$, Fig. 4C, Table 2.), with a lower potency, indicated by higher $\mathrm{EC}_{50}$ values (93.1 nM vs. $324.4 \mathrm{nM}$; Table 2). Morphine displayed similar potency values compared to rat brain, however morphine hardly enhanced the basal activity of the G-protein $(100 \% \rightarrow 118.8 \%$; Fig. 4C, Table 2), resulting a significantly lower efficacy than 14-O-methylmorphine (Table 2). At the same time the maximum efficacy of 14-Omethylmorphine was nearly the same as of the U-69593 (133.1\% vs. $130.9 \%$, Table 2), while displaying a lower $\mathrm{EC}_{50}$ value $(324.4 \mathrm{nM} v$. $69.7 \mathrm{nM}$, Table 2). For further information, see the averaged concentration-response curves of the agonists indicated in Fig. 4.

In the next step we examined the opioid receptor type selectivity of the agonist activity of 14-O-methylmorphine. To achieve this, we measured 14-O-methylmorphine -mediated G-protein activation in presence of opioid receptor type selective antagonists for $\mu$-, $\delta$ - and $\mathrm{\kappa}$ opioid receptor, namely cyprodime, naltrindole and norbinaltorphimine, respectively in $10 \mu \mathrm{M}$ concentrations again in $\left[{ }^{35} \mathrm{~S}\right] \mathrm{GTP} \gamma \mathrm{S}$ binding assays. For comparison morphine was also inhibited with cyprodime and naltrindole in the same concentrations, however norbinaltorphimine was not examined since morphine in guinea pig brain membrane homogenates failed to show considerable activity (Fig. 4C, Table 2). For control, the activity of the previously introduced reference opioid agonists, DAMGO, deltorphin II and U-69593 were also examined in the presence of their corresponding selective antagonists. According to our results, the efficacy of the reference agonists was significantly reduced in the presence of either antagonist (Table 2), reflecting their adequate activity. The $\left[{ }^{35} \mathrm{~S}\right] \mathrm{GTP} \gamma \mathrm{S}$ specific binding and 


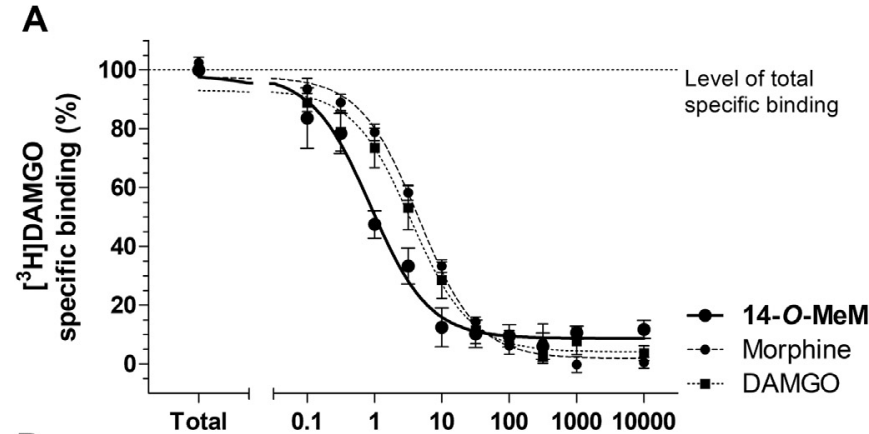

B
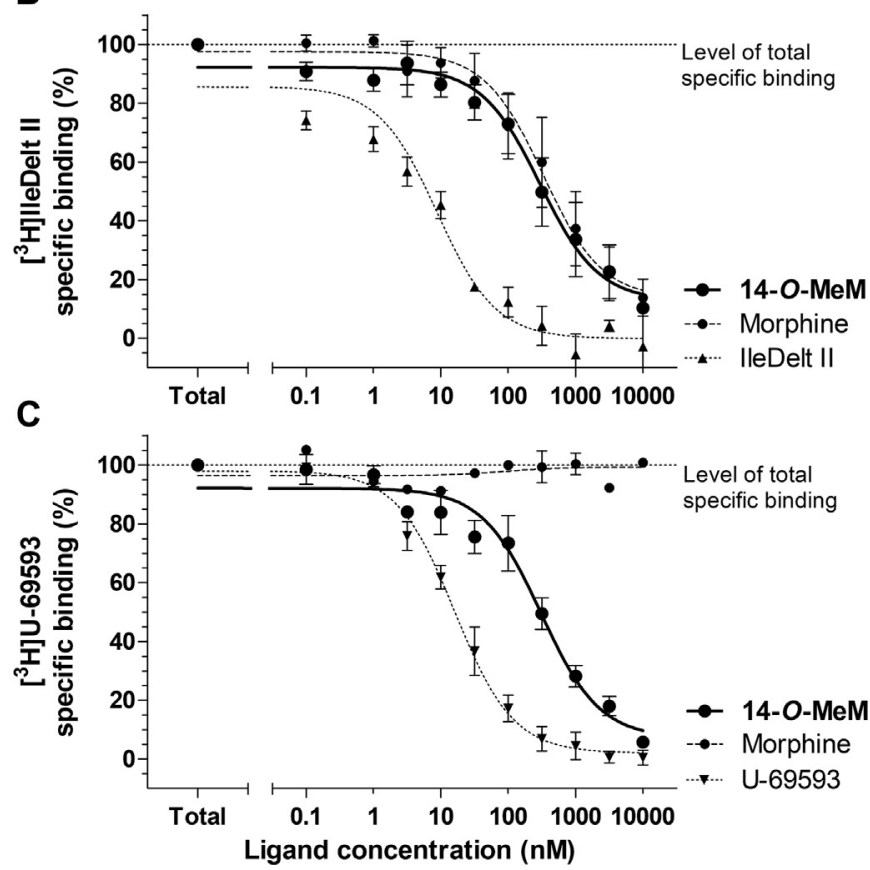

Fig. 3. Binding affinity of $14-O$-methylmorphine (14-O-MeM) to $\mu$-opioid receptor (A), $\delta$ opioid receptor (B) and $\kappa$-opioid receptor (C) compared to morphine in competition binding experiments performed in rat (A and $\mathbf{B})$ and guinea pig (C) brain membrane homogenate. For control the unlabeled form of the applied radioligands are also indicated. All figures represent the specific binding of the corresponding radioligand (A: $\left[{ }^{3} \mathrm{H}\right]$ DAMGO, B: $\left[{ }^{3} \mathrm{H}\right] \mathrm{Il} \mathrm{e}^{5,6-}$ deltorphin II [IleDelt II], C: $\left.\left[{ }^{3} \mathrm{H}\right] \mathrm{U}-69593\right)$ in percentage (means \pm S.E.M.) in the presence of increasing concentrations $(0.1 \mathrm{nM}-10 \mu \mathrm{M})$ of the indicated unlabeled ligands. "Total" on the x-axis indicates the total specific binding of the given radioligand, which is measured in the absence of the unlabeled compounds. The level of total specific binding was defined as $100 \%$ and is presented with a dotted line. The $K_{i} \pm$ S.E.M. values are presented in Table 1 .

thus the maximum efficacy of the novel morphine analogue was also decreased significantly in the presence of all the antagonists, similar to morphine. However, the maximum efficacy of 14-O-methylmorphine in the presence of cyprodime was still significantly different from basal activity similar to DAMGO and in contrast to morphine, but the potency decreased more than $1000 \mathrm{nM}$ (Table 2). Naltrindole, and norbinaltorphimine - similar to morphine - decreased the activity of $14-O$ methylmorphine to basal activity level (Table 2). The reduced activity of the compounds in the presence of the antagonists are also clearly demonstrated in the averaged concentration-response curve presented in Fig. 4B and C.

\subsection{Opioid agonist activity in mouse and rat vas deferens}

In mouse vas deferens, 14-O-methylmorphine and DAMGO inhibited the electrically-evoked mouse vas deferens muscle contractions in a concentration dependent manner (Fig. 5). Morphine showed concentration-response curve of ceiling effect (Fig. 5). The calculated $\mathrm{EC}_{50}$
(nM) values were the following: 52.55, 318.23 and 193.13 for 14-Omethylmorphine, morphine and DAMGO, respectively (Table 3). In comparison morphine only produced submaximal effect. The average $\mathrm{E}_{\max }(\%)$ values were: 86.04 for 14-O-methylmorphine, 58.36 for morphine, and 95.94 for DAMGO (Table 3). The calculated $\mathrm{K}_{\mathrm{e}}(\mathrm{nM})$ values of naloxone against 14-O-methylmorphine, morphine and DAMGO were: $1.78,1.26$ and 1.88 , respectively (Table 3 ). The $\mathrm{K}_{\mathrm{e}}$ values of norbinaltorphimine and naltrindole against 14-O-methylmorphine were $11.52 \pm 1.14(n=4)$ and $14.59 \pm 2.85(n=4)$, respectively (not indicated in Table 3 ). On the other hand, the calculated $\mathrm{K}_{\mathrm{e}}$ values for norbinaltorphimine and naltrindole against morphine were $21.57 \pm 2.45(n=3)$ and $8.22 \pm 1.50(n=4)$, respectively (not indicated in Table 3).

In rat vas deferens bioassay, 14-O-methylmorphine similar to DAMGO inhibited the muscle contractions in a concentration dependent manner in contrast to morphine which did not have any effect, indicating lower efficacy. $\mathrm{EC}_{50}(\mathrm{nM})$ values were: 270.04 for $14-O$ methylmorphine and 483.1 for DAMGO (Table 4).

\subsection{Antinociceptive activity}

To determine the antinociceptive properties of 14-O-methylmorphine, rat tail-flick test was used. After s.c. administration the peak effect of 14-O-methylmorphine was achieved at $30 \mathrm{~min}$, similarly to morphine. 14-O-methylmorphine and morphine elicited a dose-dependent antinociception. The calculated $\mathrm{ED}_{50}$ value at this time was 857 and $5259(\mathrm{nmol} / \mathrm{kg})$ for 14-O-methylmorphine and morphine, respectively (Table $5 \mathrm{~A}$ ), indicating that $14-\mathrm{O}$-methylmorphine is a more potent antinociceptive agent than morphine. Following i.c.v. administration the peak effect of both 14-O-methylmorphine and morphine were achieved after $30 \mathrm{~min}$ and the calculated $\mathrm{ED}_{50}$ value (nmol/rat) was 1.08 for $14-O-$-methylmorphine and 38.57 for morphine (Table $5 \mathrm{~B}$ ). The s.c./i.c.v. ratio was 794 for $14-O$-methylmorphine and 136 for morphine. The antinociceptive effect of both 14-O-methylmorphine and morphine at $30 \mathrm{~min}$ after s.c. and icv. administration is indicated in Fig. $6 \mathrm{~A}$ and $\mathrm{B}$, respectively.

\subsection{Inhibitory effect of systemic 14-O-methylmorphine and morphine on gastrointestinal transit in rats}

Fig. 7 depicts the inhibitory action of s.c. administered 14-O-methylmorphine and morphine on the gastrointestinal passage of charcoal suspension. The calculated inhibitory dose $\left(\mathrm{ID}_{50}\right)$ and confidence interval (nmol/kg) was 2960 (1772-4943) for 14-O-methylmorphine and 8738 (4237-18021) for morphine. These results indicate that morphine inhibited the gastrointestinal transit at 1.4 times higher dose than the antinociceptive $\mathrm{ED}_{50}$, whereas 14-O-methylmorphine at 2.2 times higher dose than its antinociceptive $\mathrm{ED}_{50}$ (see 3.3).

\section{Discussion}

This work for the first time analyzed the pharmacological properties and possible advantages of the novel opioid ligand, 14-O-methylmorphine over its parent molecule morphine or prototype $\mu$-opioid receptor selective peptide agonist, DAMGO in in vitro tests. The antinociceptive effect as well as the impact on rat intestinal transit of the test compound was also measured in vivo, with the rat tail-flick and charcoal meal assays, respectively. We found that $14-O$-methylmorphine is a $\mu$-opioid receptor agonist of higher affinity, potency, efficacy and antinociceptive activity than morphine. The displayed affinity of 14-Omethylmorphine for $\mu$-opioid receptor over $\delta$-opioid receptor or $\kappa$ opioid receptor was assessed by applying competitive binding studies, which have been reported as a good method to analyze the interaction between drugs and their receptors (Leslie, 1987). This interaction is expressed by the affinity, which is described as the ability of the ligand to bind to receptors. In these experiments, we used prototype ligands 
A

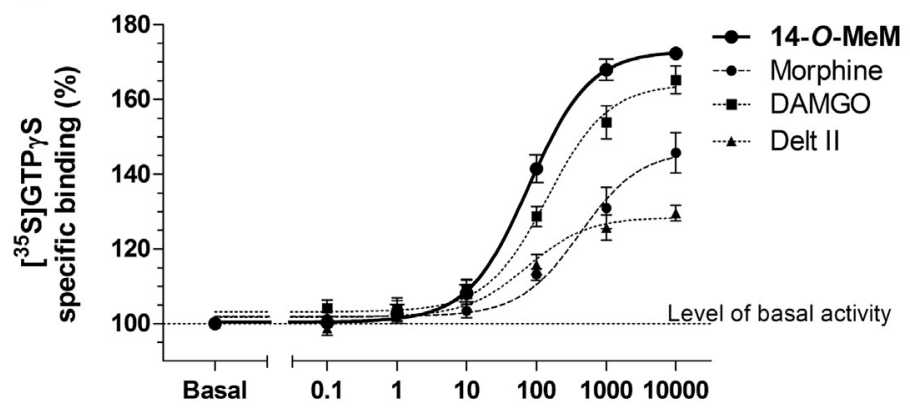

C

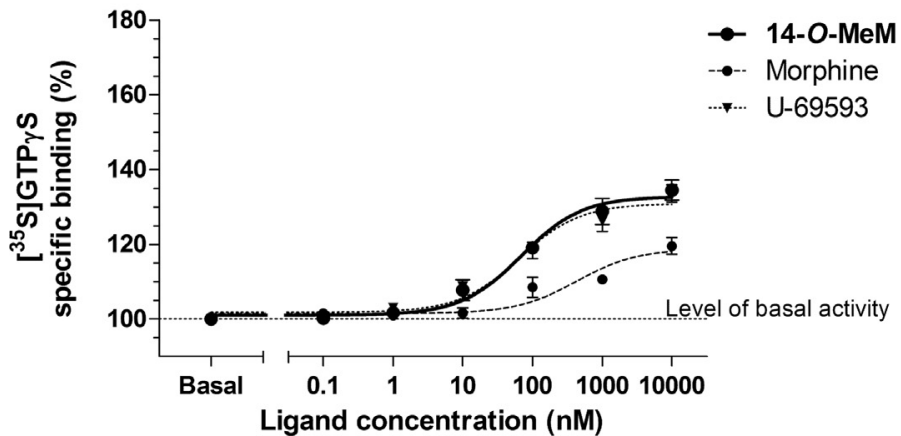

B

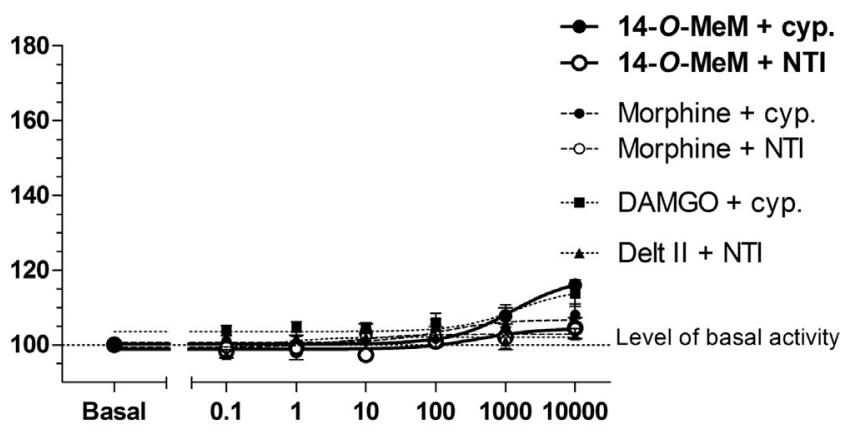

D

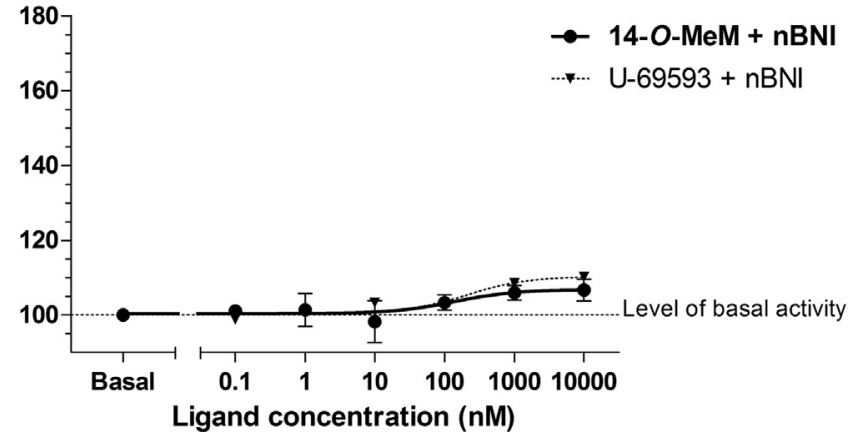

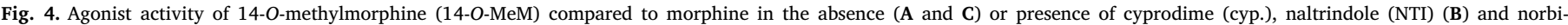

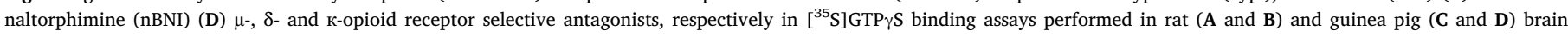

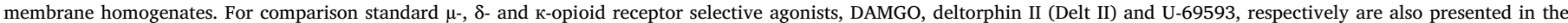

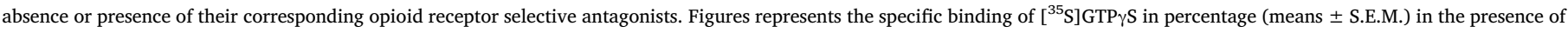

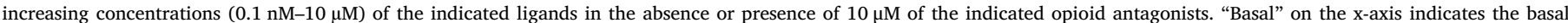

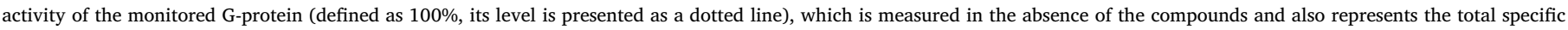
binding of $\left[{ }^{35} \mathrm{~S}\right] \mathrm{GTP} \gamma \mathrm{S}$. The $\mathrm{E}_{\max }$ and $\mathrm{EC}_{50} \pm$ S.E.M. values are presented in Table 2.

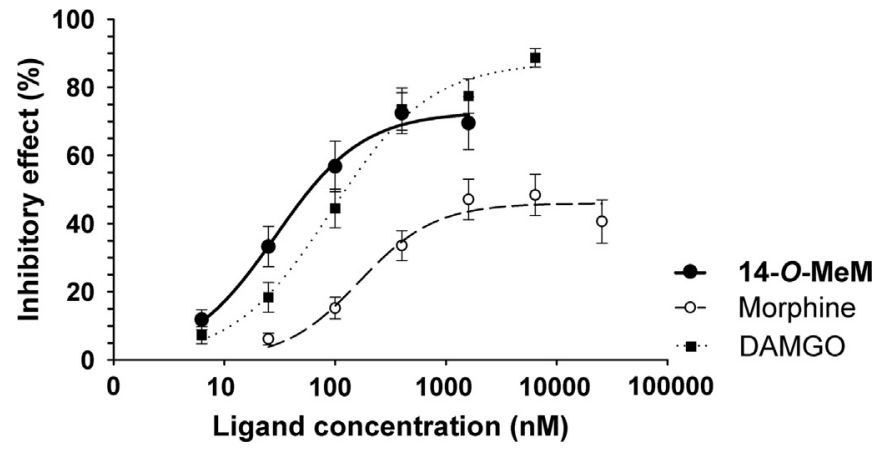

Fig. 5. The inhibitory effect of 14-O-methylmorphine (14-O-MeM) on electrically evoked contractions of mouse vas deferens compared to morphine or DAMGO. Data are presented as mean \pm S.E.M. The $\mathrm{E}_{\max }$ and $\mathrm{EC}_{50} \pm$ S.E.M. values are presented in Table 3. Experiments were performed and analyzed as described in Sections 2.5 .1 and 2.8.2, respectively.

for each opioid receptor subtypes ( $\mu$-, $\delta$ - and $\kappa$-opioid receptor) to make a comparison. 14-O-methylmorphine, and homology ligands were able to inhibit the specific binding of $\left[{ }^{3} \mathrm{H}\right]$ DAMGO, $\left[{ }^{3} \mathrm{H}\right] \mathrm{Il} \mathrm{e}^{5,6}$-deltorphin II and $\left[{ }^{3} \mathrm{H}\right] \mathrm{U}-69593$ to $\mu$-, $\delta$ - and $\kappa$-opioid receptor respectively. In opioid research these radiolabeled ligands are well characterized and widely used in the competitive binding studies to assess the affinity of novel opioids (Benyhe et al., 1992; Nevin et al., 1994; Spetea and Schmidhammer, 2012). 14-O-methylmorphine showed high selectivity and affinity for $\mu$-opioid receptor, which could be great advantage as this opioid receptor subtype has a crucial role in antinociception (McDonald, 2005). When compared to morphine, 14-O-methylmorphine displayed higher selectivity for the $\mu$-opioid receptor than for the $\delta$-opioid receptor and in contrast to morphine the test compound showed noticeable affinity for $\kappa$-opioid receptor. This additional
Table 3

The $50 \%$ effective concentration $\left(\mathrm{EC}_{50}\right)$ and the maximal effect $\left(\mathrm{E}_{\max }\right)$ of 14-O-methylmorphine (14-O-MeM), morphine and DAMGO in isolated mouse vas deferens.

\begin{tabular}{llll}
\hline Compounds & $\mathrm{E}_{\max } \pm$ S.E.M. (\%) & $\mathrm{EC}_{50} \pm$ S.E.M. (nM) & $\mathrm{K}_{\mathrm{e}} \pm$ S.E.M. (nM) \\
\hline 14-O-MeM & $\begin{array}{l}86.04 \pm 2.56^{\mathrm{a}} \\
(\mathrm{n}=7)\end{array}$ & $\begin{array}{l}52.55 \pm 16.33^{\mathrm{b}, \mathrm{c}} \\
(\mathrm{n}=7)\end{array}$ & $\begin{array}{l}1.78 \pm 0.20 \\
(\mathrm{n}=7)\end{array}$ \\
Morphine $^{\mathbf{1}}$ & $\begin{array}{l}58.36 \pm 6.92 \\
(\mathrm{n}=8)\end{array}$ & $\begin{array}{l}318.23 \pm 29.0 \\
(\mathrm{n}=8)\end{array}$ & $\begin{array}{l}1.26 \pm 0.33 \\
(\mathrm{n}=8)\end{array}$ \\
DAMGO $^{1}$ & $\begin{array}{l}95.94 \pm 1.74^{\mathrm{a}} \\
(\mathrm{n}=8)\end{array}$ & $\begin{array}{l}193.13 \pm 49.36 \\
(\mathrm{n}=8)\end{array}$ & $\begin{array}{l}1.88 \pm 0.30 \\
(\mathrm{n}=8)\end{array}$ \\
& & &
\end{tabular}

${ }^{1}$ (Lacko et al., 2012).

$\mathrm{K}_{\mathrm{e}}$ Dissociation constant of naloxone.

${ }^{a} \mathrm{P}<0.001$ compared to morphine (One-way ANOVA, Tukey's multiple comparisons post hoc test).

${ }^{\mathrm{b}} \mathrm{P}<0.01$ compared to morphine (One-way ANOVA, Tukey's multiple comparisons post hoc test).

${ }^{\mathrm{c}} \mathrm{P}<0.05$ compared to DAMGO (One-way ANOVA, Tukey's multiple comparisons post hoc test).

Table 4

The $50 \%$ effective concentration $\left(\mathrm{EC}_{50}\right)$ and the maximal effect $\left(\mathrm{E}_{\max }\right)$ of $14-O$-methylmorphine (14-O-MeM) compared to morphine and DAMGO in isolated rat vas deferens.

\begin{tabular}{lll}
\hline Compounds & $\mathrm{E}_{\max } \pm$ S.E.M. (\%) & EC $_{50} \pm$ S.E.M. (nM) \\
\hline 14-O-MeM & $\begin{array}{l}89.69 \pm 3.54 \\
(\mathrm{n}=7)\end{array}$ & $\begin{array}{l}270.04 \pm 73.51 \\
(\mathrm{n}=7)\end{array}$ \\
Morphine & $\begin{array}{l}\text { No effect } \\
(\mathrm{n}=6)\end{array}$ & N.D. \\
DAMGO $^{1}$ & $\begin{array}{l}80.58 \pm 3.74 \\
(\mathrm{n}=4)\end{array}$ & $\begin{array}{l}483.1 \pm 57.29 \\
(\mathrm{n}=4)\end{array}$ \\
& &
\end{tabular}

N.D.: Not determined

1 (Lacko et al., 2012) 
Table 5

(A and $\mathrm{B})$. Antinociceptive potencies $\left(\mathrm{ED}_{50}\right)$ of 14-O-methylmorphine (14-O-MeM) and morphine against radiant heat induced nociception in rat tail-flick test after 30, 60 and 120 min of s.c. administration (5/A) and after 10, 20, 30 and 60 min of i.c.v. administration $(5 / B)$

\begin{tabular}{|c|c|c|c|}
\hline \multicolumn{4}{|l|}{ A } \\
\hline \multirow[t]{2}{*}{ Compounds } & \multicolumn{3}{|c|}{$\begin{array}{l}\mathrm{ED}_{50} \text { (sc., } \mathrm{nmol} / \mathrm{kg} \text { ) } \\
\text { Time after sc. administration (min) }\end{array}$} \\
\hline & 30 & 60 & 120 \\
\hline 14-O-MeM & $\begin{array}{l}857^{\mathrm{a}} \\
(451-1629)\end{array}$ & $\begin{array}{l}1345 \\
(743-2437)\end{array}$ & - \\
\hline Morphine & $\begin{array}{l}5259^{\mathrm{a}} \\
(3637-7603)\end{array}$ & $\begin{array}{l}6270 \\
(4344-9049)\end{array}$ & $\begin{array}{l}18,845 \\
(11,279-31,486)\end{array}$ \\
\hline
\end{tabular}

Compounds $\quad \mathrm{ED}_{50}$ (icv., nmol/animal)

Time after icv. administration (min)

\begin{tabular}{lllll}
\cline { 2 - 5 } & $\mathbf{1 0}$ & $\mathbf{2 0}$ & $\mathbf{3 0}$ & $\mathbf{6 0}$ \\
\hline \multirow{2}{*}{ 14-O-MeM } & 1.12 & 1.15 & $1.08^{\mathrm{a}}$ & 2.85 \\
& $(0.63-1.96)$ & $(0.68-1.95)$ & $(0.64-1.80)$ & $(1.5-5.41)$ \\
Morphine & - & $55.37^{1}$ & $38.57^{\mathrm{a}, 1}$ & $49.15^{1}$ \\
& & $(32.04-94.87)$ & $(22.08-67.49)$ & $(28.93-83.67)$
\end{tabular}

Data in parentheses are $95 \%$ confidence limits. At least 5 animals per dose group and 3-4 doses were used for each $\mathrm{ED}_{50}$ determinations.

${ }^{1}$ (Lacko et al., 2012).

a Peak of effect.

receptorial activity might have significant impact on the CNS functions of the novel compound; it may enhance the $\mu$-opioid receptor-induced antinociceptive action (Kivell and Prisinzano, 2010), and in parallel may reduce the euphoric property and abuse potential (Funada et al., 1993).

The competition binding studies had only shown that the ligand has affinity for the receptors but to approve whether it is full agonist, partial agonist or antagonist another assays were needed. Therefore, functional $\left[{ }^{35} \mathrm{~S}\right] \mathrm{GTP} \gamma \mathrm{S}$ binding and mouse vas deferens assays were used to estimate the agonist character of the novel compound and to compare it to that of reference compounds. These assays are suitable to determine both agonist potency and efficacy, which are defined in terms of $\mathrm{EC}_{50}$ and $\mathrm{E}_{\max }$, respectively (Leslie, 1987; Strange, 2010). The $\left[{ }^{35} \mathrm{~S}\right] \mathrm{GTP} \gamma \mathrm{S}$ binding assay monitors the ability of a test compound to activate the G-protein, which is the first and crucial step in GPCR signaling. The mouse vas deferens bioassay represents a one step closer approach to a more physiological circumstance for agonist activity measurements compared to brain membrane homogenates in receptor

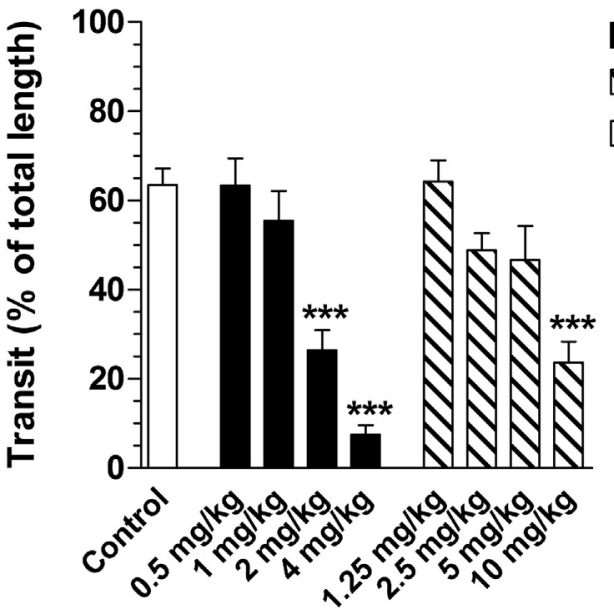

Fig. 7. The effect of 14-O-methylmorphine (14-O-MeM) on rat gastrointestinal transit compared to morphine and control (saline). The figure represents the inhibition of gastrointestinal transit in percentage (means \pm S.E.M.) of total length compared to saline treated group (control) in the presence of $14-\mathrm{O}-\mathrm{MeM}$ and morphine in the indicated dosages. *: indicates the significant difference compared to control (One-way ANOVA, Tukey's multiple comparisons post hoc test, $\mathrm{P}<0.001$ ). The experiment was performed and analyzed as discussed in Sections 2.7 and 2.8.3, respectively.

binding assays. In these studies, we found that 14-O-methylmorphine is more potent than the reference compounds and showed full agonist character indicated by the $\mathrm{E}_{\max }$ value, similar to DAMGO and in contrast to morphine. DAMGO is known to be a full peptide agonist at $\mu$ opioid receptor (Gassaway et al., 2014; Hirning et al., 1985; AlKhrasani et al., 2001). Additionally, selective opioid receptor subtype antagonists significantly reduced the G-protein activity of $14-\mathrm{O}$-methylmorphine, indicating that its agonist activity is mediated by either the $\mu$-, $\delta$ - and $\kappa$-opioid receptor. However, the preference for $\mu$-receptor is already addressed in the binding assay. Cyprodime at higher test concentration failed to totally reverse the maximal effect $\left(E_{\max }\right)$ achieved by $14-O$-methylmorphine or DAMGO to the basal values. This can be explained by the own activity of cyprodime which was $111.4 \%$ ( \pm 2.12 ) based on our present results and earlier reports (Márki et al., 1999). In addition, we have to take into the account the affinity, because reversible interaction was occurred between 14-O-methylmorphine or DAMGO and cyprodime, and the concentration dictates the observed effect. That means increasing the concentration of cyprodime might result in an $\mathrm{E}_{\max }$ close to basal activity or to that achieved by cyprodime alone. In mouse vas deferens, the $\mathrm{K}_{\mathrm{e}}$ values of naloxone (a non-selective opioid antagonist) against morphine, DAMGO and 14-Omethylmorphine were within the range of $1.26-1.80 \mathrm{nM}$ and there were no significant differences between the values. These results indicate
A

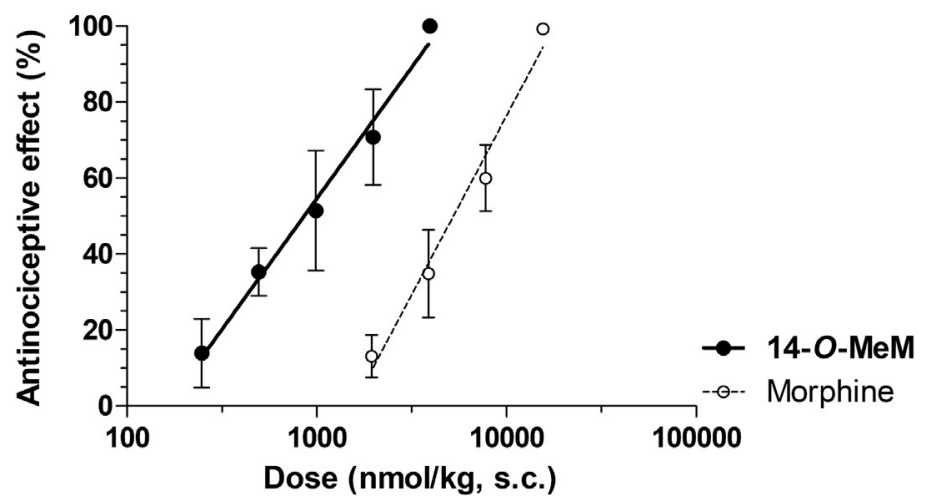

B

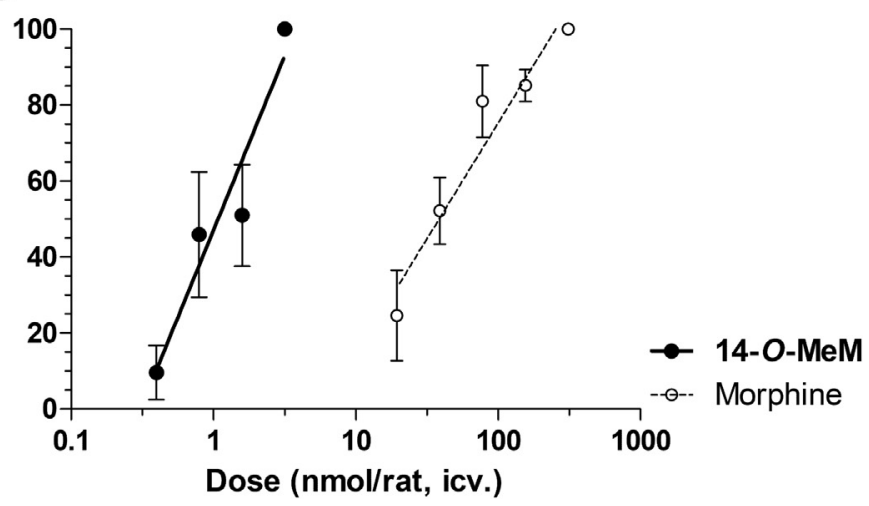

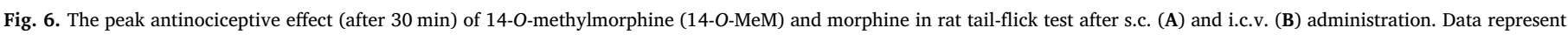
means \pm S.E.M. and were analyzed as described in Section 2.8.3. The experiments were performed according to Section 2.6 . 
that all compounds are $\mu$-opioid receptor selective agonists and correspond well with our competition binding results and with previous data regarding to DAMGO and morphine reported by our or other teams (Khalefa et al., 2013; Lacko et al., 2012; Miller et al., 1986). Of note, the $\mathrm{K}_{\mathrm{e}}$ values of norbinaltorphimine was significantly lower when tested against 14-O-methylmorphine compared to against morphine.

Since these experiments were carried out in brain homogenates and mouse vas deferens, and these tissues have been reported to host opioid receptors of high reserve (Leslie, 1987), therefore we extended our study to test the action of test compound in rat vas deferens. Rat vas deferens hosts $\mu$-opioid like receptors of low reserve (Al-Khrasani et al., 2007; Miller et al., 1986; Smith and Rance, 1983) and opioid of high efficacy will act as full agonist. Our findings indicate that 14-O-methylmorphine similar to DAMGO but not to morphine produced high efficacy. The full and partial agonist character of an opioid agonist is an important issue, since many reports described that a decrease in antinociceptive efficacy of currently used opioid is a consequence of decrease in opioid receptor reserve (Al-Khrasani et al., 2001, 2007; Khalefa et al., 2013; Riba et al., 2010). Therefore, only opioid of high efficacy (having spare receptors) will be able to produce antinociception by chronic administration without substantial loss of effect. Decrease in opioid receptor has been observed in spinal diabetic rats (Shaqura et al., 2013), suffering of neuropathic pain. In such pain, we assume that opioids of high efficacy might be of pharmacological values.

Finally, we were curious in the antinociceptive and side effect of the novel compound, since the in vitro data not always fit the researcher's expectation when the study carried out in a complex biological system. Therefore, we extended our study to determine the antinociceptive action of 14-O-methylmorphine in vivo, as well as its inhibitory effect on gastrointestinal transit. For this study, acute heat-induced pain (rat tailflick) and charcoal meal tests were chosen. In good accordance with the in vitro findings, 14-O-methylmorphine increased the pain threshold in a dose dependent manner and proved to be a more potent antinociceptive agent than morphine when injected systemically or centrally. Interestingly, the test compound compared to morphine showed a somewhat weaker inhibitory action on gastrointestinal peristalsis. This result was seen when ratios of antinociception $\left(\mathrm{ED}_{50}\right)$ and antitransit $\left(\mathrm{ID}_{50}\right)$ values for morphine and 14-O-methylmorphine were compared. These results suggest that the test compound has less pronounced gastrointestinal side effects, though we did not expect it, since it showed high efficacy in in vitro assays, implying that it behaves as a full agonist. It is noteworthy that similar promising favorable profile had also been reported by Holtman and coworkers for morphine-6-Osulfate (Holtman et al., 2010), but in its case the partial agonistic property might explain the mild gastrointestinal inhibitory action (Lackó et al., 2012; Al-Khrasani et al., 2001). Morphine, on the other hand, is also a partial agonist, but induced more pronounced antitransit effect than the other two derivatives. Further studies are needed to verify these differences and their translational relevance.

The development of 14-alkyloxymorphinan analogues was first represented by the synthesis of 14-O-methyloxymorphone (Schmidhammer et al., 1984) followed by others (Spetea and Schmidhammer, 2012). Similar strategy was carried out for the synthesis of 14-O-methylmorphin-6-O-sulfate (Lacko et al., 2012) and here for 14-O-methylmorphine. 14-O-methylmorphine similar to $14-O$-methyloxymorphone and 14-O-methylmorphin-6-O-sulfate displayed improved affinity, agonist activity and antinociceptive potency compared to their parent compound (oxymorphone and morphine-6-O-sulfate, respectively) (Lacko et al., 2012; Spetea and Schmidhammer, 2012).

Questions might be raised around clinical value of such analogues. MOR agonists of such pharmacological properties (high potency and efficacy) can be advantageous in the terms of clinical use, because as above mentioned, animal models of neuropathic pain have been reported to display decrease in the $\mu$-opioid receptor reserve (Shaqura et al., 2013). Therefore, we can assume that opioid agonists of high efficacy might be beneficial in such pain conditions. Also, there is the possibility that these compounds have a better tolerance profile probably because of their high efficacy (Kiraly et al., 2015). Although the antinociceptive property of the test compound is promising, the noticed interaction with $\kappa$-opioid receptor and other not determined safety profiles (respiratory depression and addiction) will be studied in further pharmacological, pharmacokinetic and toxicological assays in the future.

\section{Conclusion}

We investigated the highly effective novel compound 14-O-methylmorphine. Our results strengthen the hypothesis and our previous findings that these kind of structure modifications of morphine lead to a better pharmacological profile in terms of efficacy and potency. Additionally, 14-O-methylmorphine showed high selectivity for $\mu$ opioid receptor and was highly effective antinociceptive agent of decreased antitransit effect compared to morphine after systemic administration. These new agents can be a new way to alleviate pain in conditions like neuropathic or inflammatory pain syndromes when it's a major challenge to treat with the drugs that are in clinical practice.

\section{Conflict of interest}

We have no conflict of interest.

\section{Acknowledgment}

This study was supported by the National Research Development and Innovation Office (NKFIH, Hungary, grant number: OTKA 108518) and Semmelweis University (grant number: AOK/DH/148-7/2015). F. Zádor would like to thank the Hungarian Academy of Sciences for granting the two-year Postdoctoral Fellowship.

\section{References}

Al-Khrasani, M., Orosz, G., Kocsis, L., Farkas, V., Magyar, A., Lengyel, I., Benyhe, S. Borsodi, A., Rónai, A.Z., 2001. Receptor constants for endomorphin-1 and endomorphin-1-ol indicate differences in efficacy and receptor occupancy. Eur. J. Pharmacol. 421, 61-67.

Al-Khrasani, M., Spetea, M., Friedmann, T., Riba, P., Király, K., Schmidhammer, H., Furst, S., 2007. DAMGO and 6beta-glycine substituted 14-O-methyloxymorphone but not morphine show peripheral, preemptive antinociception after systemic administration in a mouse visceral pain model and high intrinsic efficacy in the isolated rat vas deferens. Brain Res. Bull. 74, 369-375.

Benyhe, S., Farkas, J., Tóth, G., Wollemann, M., 1997. Met5-enkephalin-Arg6-Phe7, an endogenous neuropeptide, binds to multiple opioid and nonopioid sites in rat brain. J. Neurosci. Res. 48, 249-258.

Benyhe, S., Szücs, M., Borsodi, A., Wollemann, M., 1992. Species differences in the stereoselectivity of kappa opioid binding sites for [3H]U-69593 and [3H] ethylketocyclazocine. Life Sci. 51, 1647-1655.

Cheng, Y., Prusoff, W., 1973. Relationship between the inhibition constant (K1) and the concentration of inhibitor which causes 50 per cent inhibition (I50) of an enzymatic reaction. Biochem. Pharmcol. 22, 3099-3108.

Debono, D.J., Hoeksema, L.J., Hobbs, R.D., 2013. Caring for patients with chronic pain: pearls and pitfalls. J. Am. Osteopath. Assoc. 113, 620-627.

Frey, K.A., Albin, R.L., 2001. Receptor Binding Techniques. Current Protocols in Neuroscience/Editorial Board, Jacqueline N. Crawley ... [et al.] Chapter 1, Unit1.4.

Funada, M., Suzuki, T., Narita, M., Misawa, M., Nagase, H., 1993. Blockade of morphine reward through the activation of kappa-opioid receptors in mice. Neuropharmacology 32, 1315-1323.

Fürst, S., 1999. Transmitters involved in antinociception in the spinal cord. Brain Res. Bull. 48, 129-141.

Fürst, S., Riba, P., Friedmann, T., Tímar, J., Al-Khrasani, M., Obara, I., Makuch, W. Spetea, M., Schütz, J., Przewlocki, R., Przewlocka, B., Schmidhammer, H., 2005. Peripheral versus central antinociceptive actions of 6-amino acid-substituted derivatives of 14-O-methyloxymorphone in acute and inflammatory pain in the rat. $\mathrm{J}$. Pharmacol. Exp. Ther. 312, 609-618.

Fürst, Z., Búzás, B., Friedmann, T., Schmidhammer, H., Borsodi, A., 1993. Highly potent novel opioid receptor agonist in the 14-alkoxymetopon series. Eur. J. Pharmacol. 236, 209-215.

Gassaway, M.M., Rives, M.L., Kruegel, A.C., Javitch, J.A., Sames, D., 2014. The atypical antidepressant and neurorestorative agent tianeptine is a mu-opioid receptor agonist. Transl. Psychiatry 4, e411.

Hirning, L.D., Mosberg, H.I., Hurst, R., Hruby, V.J., Burks, T.F., Porreca, F., 1985. Studies 
in vitro with ICI 174,864, [D-Pen2, D-Pen5]-enkephalin (DPDPE) and [D-Ala2, NMePhe4, Gly-ol]-enkephalin (DAGO). Neuropeptides 5, 383-386.

Holtman Jr., J.R., Crooks, P.A., Johnson-Hardy, J., Wala, E.P., 2010. Antinociceptive effects and toxicity of morphine-6-O-sulfate sodium salt in rat models of pain. Eur. J. Pharmacol. 648, 87-94.

Khalefa, B.I., Mousa, S.A., Shaqura, M., Lackó, E., Hosztafi, S., Riba, P., Schäfer, M., Ferdinandy, P., Fürst, S., Al-Khrasani, M., 2013. Peripheral antinociceptive efficacy and potency of a novel opioid compound 14-O-MeM6SU in comparison to known peptide and non-peptide opioid agonists in a rat model of inflammatory pain. Eur. J. Pharmacol. 713, 54-57.

Kiraly, K., Caputi, F.F., Hanuska, A., Kato, E., Balogh, M., Koles, L., Palmisano, M., Riba, P., Hosztafi, S., Romualdi, P., Candeletti, S., Ferdinandy, P., Furst, S., Al-Khrasani, M., 2015. A new potent analgesic agent with reduced liability to produce morphine tolerance. Brain Res. Bull. 117, 32-38.

Kivell, B., Prisinzano, T.E., 2010. Kappa opioids and the modulation of pain. Psychopharmacology 210, 109-119.

Kobylecki, R.J., Carling, R.W., Lord, J.A.H., Smith, C.F.C., Lane, A.C., 1982. Common anionic receptor site hypothesis: its relevance to the antagonist action of naloxone. J. Med. Chem. 25, 116-120.

Koob, G.F., Sanna, P.P., Bloom, F.E., 1998. Neuroscience of addiction. Neuron 21, 467-476.

Kosterlitz, H.W., Watt, A.J., 1968. Kinetic parameters of narcotic agonists and antagonists, with particular reference to $\mathrm{N}$-allylnoroxymorphone (naloxone). $\mathrm{Br}$. J Pharmacol. Chemother. 33, 266-276.

Lacko, E., Varadi, A., Rapavi, R., Zador, F., Riba, P., Benyhe, S., Borsodi, A., Hosztafi, S., Timar, J., Noszal, B., Furst, S., Al-Khrasani, M., 2012. A novel $\mu$-opioid receptor ligand with high in vitro and in vivo agonist efficacy. Curr. Med. Chem. 19, 4699-4707.

Leslie, F.M., 1987. Methods used for the study of opioid receptors. Pharmacol. Rev. 39, 197-249.

Litchfield Jr., J.T., Wilcoxon, F., 1949. A simplified method of evaluating dose-effect experiments. J. Pharmacol. Exp. Ther. 96, 99-113.

Márki, Á., Monory, F., Ötvös, F., Tóth, G., Krassnig, R., Schmidhammer, H., Traynor, J.R., Roques, B.P., Maldonado, R., Borsodi, A., 1999. $\mu$-Opioid receptor specific antagonist cyprodime: characterization by in vitro radioligand and [35S]GTP $\gamma$ S binding assays. Eur. J. Pharm. 383, 209-2014.

McDonald, J., 2005. Opioid receptors. Continuing education in anaesthesia. Crit. Care Pain. 5, 22-25.

Miller, L., Shaw, J.S., Whiting, E.M., 1986. The contribution of intrinsic activity to the action of opioids in vitro. Br. J. Pharmacol. 87, 595-601.

Nevin, S.T., Kabasakal, L., Otvös, F., Töth, G., Borsodi, A., 1994. Binding characteristics of the novel highly selective delta agonist, [3H]IIe5,6deltorphin II. Neuropeptides 26, 261-265.

Razdan, R.K., Ghosh, A.C., 1980. 17-Cyclobutylmethyl-4,5.Alpha.-e Poxy-3-Hydroxy-14Methoxy-8.Alpha.-Methylmorphinan-6-one, and Method of Treating Pain with It.
Patent No 4370333.

Riba, P., Friedmann, T., Király, K.P., Al-Khrasani, M., Sobor, M., Asim, M.F., Spetea, M., Schmidhammer, H., Furst, S., 2010. Novel approach to demonstrate high efficacy of mu opioids in the rat vas deferens: a simple model of predictive value. Brain Res. Bull. 81, 178-184.

Rónai, A.Z., Gráf, L., Székely, J.I., Dunai-Kovács, Z., Bajusz, S., 1977. Differential behaviour of LPH-(61-91)-peptide in different model systems: comparison of the opioid activities of LPH-(61-91)-peptide and its fragments. FEBS Lett. 74, 182-184.

Schmidhammer, H., Aeppli, L., Atwell, L., Fritsch, F., Jacobson, A.E., Nebuchla, M., Sperk, G., 1984. Synthesis and biological evaluation of 14-alkoxymorphinans. 1. Highly potent opioid agonists in the series of (-)-14-methoxy-N-methylmorphinan-6-ones. J. Med. Chem. 27, 1575-1579.

Schmidhammer, H., Smith, C.F., Erlach, D., Koch, M., Krassnig, R., Schwetz, W., Wechner, C., 1990. Synthesis and biological evaluation of 14-alkoxymorphinans. 3. extensive study on cyprodime-related compounds. J. Med. Chem. 33, 1200-1206.

Shaqura, M., Khalefa, B.I., Shakibaei, M., Winkler, J., Al-Khrasani, M., Fürst, S., Mousa, S.A., Schäfer, M., 2013. Reduced number, G protein coupling, and antinociceptive efficacy of spinal mu-opioid receptors in diabetic rats are reversed by nerve growth factor. J. Pain.: Off. J. Am. Pain. Soc. 14, 720-730.

Sim, L.J., Selley, D.E., Childers, S.R., 1995. In vitro autoradiography of receptor-activated G proteins in rat brain by agonist-stimulated guanylyl 5'-[gamma-[35S]thio]-triphosphate binding. Proc. Natl. Acad. Sci. USA 92, 7242-7246.

Smith, C.F., Rance, M.J., 1983. Opiate receptors in the rat vas deferens. Life Sci. 33 (Suppl. 1), S327-S330.

Spetea, M., Schmidhammer, H., 2012. Recent advances in the development of 14-alkoxy substituted morphinans as potent and safer opioid analgesics. Curr. Med. Chem. 19, 2442-2457.

Spetea, M., Schullner, F., Moisa, R.C., Berzetei-Gurske, I.P., Schraml, B., Dorfler, C., Aceto, M.D., Harris, L.S., Coop, A., Schmidhammer, H., 2004. Synthesis and biological evaluation of 14-alkoxymorphinans. 21. novel 4-alkoxy and 14-phenylpropoxy derivatives of the mu opioid receptor antagonist cyprodime. J. Med. Chem. 47, 3242-3247.

Strange, P.G., 2010. Use of the GTP $\gamma$ S ([35S]GTP $\gamma$ S and Eu-GTP $\gamma$ S) binding assay for analysis of ligand potency and efficacy at $\mathrm{G}$ protein-coupled receptors. Br. J. Pharmacol. 161, 1238-1249.

Traynor, J.R., Nahorski, S.R., 1995. Modulation by mu-opioid agonists of guanosine-5'-O(3-[35S] thio)triphosphate binding to membranes from human neuroblastoma $\mathrm{SH}-$ SY5Y cells. Mol. Pharmacol. 47, 848-854.

Vera, G., Castillo, M., Cabezos, P.A., Chiarlone, A., Martin, M.I., Gori, A., Pasquinelli, G., Barbara, G., Stanghellini, V., Corinaldesi, R., De Giorgio, R., Abalo, R., 2011. Enteric neuropathy evoked by repeated cisplatin in the rat. Neurogastroenterol. Motil. 23 (370-378), e162-e373.

Zádor, F., Kocsis, D., Borsodi, A., Benyhe, S., 2014. Micromolar concentrations of rimonabant directly inhibits delta opioid receptor specific ligand binding and agonistinduced G-protein activity. Neurochem. Int. 67, 14-22. 